\title{
Ficciones de libertad en la Castilla moderna. Fiscalidad, poder y villazgo en el reino de Murcia (1665-1700)
}

\section{Fictions of freedom in modern Castile. Taxation, power and villazgo in the Kingdom of Murcia (1665-1700)}

\author{
Vicente Montojo Montojo \\ Real Academia Alfonso X el Sabio \\ vicente.montojo@um.es \\ https://orcid.org/0000-0001-6519-6559 \\ Julio D. MuÑoz Rodríguez \\ Consejería de Educación. Región de Murcia \\ juliodavid.munoz@murciaeduca.es \\ https://orcid.org/0000-0002-4544-5383
}

Fecha de recepción: 13-03-2020

Fecha de aceptación: 06-06-2020

\section{RESUMEN}

Se revisan en este texto las concesiones de villazgos en el siglo XVII en el reino de Murcia, pues fueron muy pocos los del reinado de Felipe IV, como las del siglo XVIII. Pero se hace no desde el punto de vista de la mera concesión como merced regia, sino desde la articulación discursiva de los grupos que promovieron los villazgos y de los que se enfrentaron a ellos. De aquí el título del artículo, pues los motivos alegados por los promotores no se redujeron a ficciones de libertad. Se plantea además que la proliferación de villazgos fue paralela a una remodelación del espacio regnícola en superintendencias fiscales o de rentas provinciales y nuevos corregimientos, que entraron además en la almoneda de mercedes o concesiones característica de esta época.

Palabras clave: Fiscalidad, Villazgo, Carlos II.

Topónimos: Corona de Castilla, Reino de Murcia

Períodos: siglo XVII.

\section{ABSTRACT}

This text reviews the concession of villazgos in the 17th century in the Kingdom of Murcia, since there were very few during the reign of Felipe IV, like those of the 18th century. Not, however, from the point of view of the mere concession as royal grace, but via discursive articulation of the groups that promoted the villazgos and those who opposed them. Hence the title of the article, as the motives alleged by advocates were not reduced to fictions of freedom. It is also suggested that the 
proliferation of villazgos ran parallel to a remodeling of the reign's space in fiscal superintendencies or of provincial tax revenues and new administrative areas, which also entered in the graces or concessions market characteristic of this era.

Key words: Taxation, royal charter of township, Carlos II.

Toponyms: Castilian Crown, Kingdom of Murcia.

Period: 17th Century.

\section{VILLAZGO: CONCEPTO Y METODOLOGÍA DE UN OBJETO HISTORIO- GRÁFICO}

La exención o emancipación de villazgos fue un hecho frecuente en España durante los siglos XV al XVII, sobre todo como efecto de la venta de jurisdicciones, ya fueran señoríos o villas. Este recurso fiscal, que no deja de poseer una trascendencia política y social, se hizo dentro de un proceso más general de almoneda de mercedes, que, como han puesto especialmente de relieve los profesores A. Marcos Martín y F. Andújar Castillo, terminó afectando a alcabalas, enclaves, hidalguías, hábitos de órdenes militares, encomiendas, títulos nobiliarios o hasta los principales cargos de la administración americana ${ }^{1}$. En algunos territorios dio lugar a cambios o redistribuciones del espacio político de cierta consideración, como ocurrió en Segovia a lo largo del siglo XVII², pero lo curioso es que estas ventas de villazgos coincidirán con la redefinición de las provincias con fines fiscales, caso de Murcia (1656), La Mancha (1691) y Cuenca ${ }^{3}$.

En consecuencia, no es un asunto menor estos procesos de separación jurisdiccional que se dieron a lo largo de los tiempos modernos. Sus múltiples posibilidades de análisis otorgan a los villazgos una posición privilegiada para percibir las consecuencias de la venalidad, la práctica política entre Corona y población —especialmente la que habitaba el espacio rural—, así como la construcción de discursos políticos desde las instituciones locales que la representaban. El contexto temporal que abarca esta investigación corresponde al reinado de Carlos II, tradicionalmente relegado por la historiografía, pese a que es cada vez más patente su carácter de transición con la etapa borbónica y su relevancia en la formulación y adaptación de soluciones fiscales que permitieron la "conservación" de la Monarquía 4 . Por su parte, el espacio en el que se ubica viene dado por el reino de Murcia

1 Un contexto global en A. Marcos Martín, "Enajenaciones por precio del patrimonio regio en los siglos XVI y XVII. Balance historiográfico y perspectivas de análisis", en R. López y D. González Lopo, (coords.), Balance de la historiografía modernista, 1973-2001. Actas del VI Coloquio de Metodología Histórica Aplicada, Santiago de Compostela, Xunta de Galicia, 2003, pp. 419-443; y F. Andújar Castillo, Necesidad y venalidad: España e Indias, 1704-1711, Madrid, Centro de Estudios Políticos y Constitucionales, 2008, y P. Ponce Leiva y F. Andújar Castillo (eds.), Mérito, venalidad y corrupción en España y América, Valencia, Albatros, 2016.

2 E. Gallego Lázaro, "La reorganización de la comunidad de ciudad y tierra de Segovia durante la Edad Moderna. Las ventas de lugares en el siglo XVII", Studia Historica. Historia Moderna, 38/2, (2016), pp. 387-424; y S. Truchuelo García, "Villas y aldeas en el Antiguo Régimen: conflicto y consenso en el marco local castellano", Mundo Agrario, 14/27, (2013), http://www.memoria.fahce.unlp.edu.ar/art_revistas/pr.5951/ pr.5951.pdf (Consulta: 15-1-2020).

3 M. Á. Rodríguez Doménech y E. Rodríguez Espinosa, "El territorio de la Intendencia de La Mancha en el Catastro de Ensenada. Antecedentes, configuración y evolución posterior", Revista Catastro, 80, (2014), pp. 89-148, v. 96-7, y para el caso murciano, J. D. Muñoz Rodríguez, "El superintendente austriaco y el intendente borbónico. La evolución de un modelo de gestión de los recursos fiscales en la Monarquía Hispánica", Las monarquías española y francesa (ss. XVI-XVII): ¿dos modelos políticos?, Madrid, Casa de Velázquez, 2010, pp. 131-144.

4 Remitimos a los estudios contenidos en M. C. Saavedra (ed.), La decadencia de la monarquía hispánica 
que, si bien cuenta con ritmos propios en el crecimiento económico, la ocupación del territorio y el desarrollo político, las causas, medios y resultados de esta clase de litigios pueden extrapolarse en términos relativos al conjunto castellano.

La riqueza de lecturas que pensamos posee el estudio de villazgos está condicionada a la variedad de fuentes archivísticas que se utilicen. Las diferentes perspectivas que en estos pleitos jurisdiccionales se plantean sólo pueden percibirse a partir de la información que suministra la documentación generada en los diversos estratos administrativos que se relacionaban con estos conflictos; es decir, no sólo los tribunales cortesanos, sino también los propios ámbitos locales donde surgían estas reclamaciones. Es por esta razón por lo que las fuentes empleadas han sido muy heterogéneas, abarcando desde los memoriales, consultas y decretos de algunos consejos reales, conservados en el Archivo General de Simancas y en el Archivo Histórico Nacional de Madrid, así como las actas capitulares de los concejos afectados o los poderes y procuraciones formalizados ante los escribanos y contenidos en los archivos históricos provinciales.

\section{EL VILLAZGO EN EL MERCADO DE MERCEDES}

Si el dinero fue el nervio de la guerra, ésta también fue a su vez el motor que asentó el poder de los monarcas y el medio que contribuyó a consolidar a las élites en sus respectivos ámbitos locales ${ }^{5}$. Este proceso fue posible gracias a la creciente coerción fiscal ejercida sobre los súbditos, justificada en un discurso jurídico-teológico que sostenía la obligación contributiva del vasallo en la defensa de su príncipe. El incremento progresivo de la detracción fiscal requirió de ir acompañado de fórmulas que trataran de mantener un cierto consenso social; se hacía preciso establecer mecanismos que permitiesen a la población, y especialmente a sus élites, algún tipo de beneficio que ayudase a identificar las empresas del soberano como necesidades propias, o al menos como una oportunidad para extraer beneficios de todo tipo ${ }^{6}$. De lo contrario, los intentos de detraer recursos a la población podían derivar en el surgimiento de movimientos de resistencia a ese aumento de la carga impositiva, en forma de rebeliones o motines tan frecuentes en las sociedades europeas.

En el caso de la Corona de Castilla, esta gradual ocupación de nuevos espacios fiscales por parte del monarca fue efectuada con el consentimiento básico de la población, bien en forma de servicio, como ocurría con los Millones, los cuales se aprobaban en cortes o se prorrogaban en los mismos concejos de voto después de 16657; o bien por medio de

en el siglo XVII. Viejas imágenes y nuevas aportaciones, Madrid, Biblioteca Nueva, 2016.

5 I. A. A. Thompson, "Patronato real e integración política en las ciudades castellanas bajo los Austrias", en J. I. Fortea Pérez (ed.), Imágenes de la diversidad. El mundo urbano en la Corona de Castilla (ss. XVI-XVIII), Santander, Universidad de Cantabria, 1997, pp. 475-496.

6 I. A. A. Thompson, "Do ut des: la economía política del 'servicio' en la Castilla Moderna", en A. Esteban Estríngana (ed.), Servir al Rey en la Monarquía de los Austrias. Medios, fines y logros del servicio al soberano en los siglos XVI y XVII, Madrid, Sílex, 2012, pp. 283-296. También J. J. Ruiz Ibáñez, "El final de un sueño imperial: guerra y poder en Castilla tras 1635", Studia historica. Historia Moderna, 41-1, (2019), pp. 259-288. Dos ejemplos de estas consecuencias políticas para la población castellana en E. Soria Mesa, El cambio inmóvil: transformaciones y permanencias en una élite de poder (Córdoba, ss. XVI-XIX), Córdoba, Ediciones de La Posada, 2000; y J. D. Muñoz Rodríguez, Damus ut des. Los servicios de la ciudad de Murcia a la Corona a finales del siglo XVII, Murcia, Real Academia Alfonso X el Sabio (AAXS), 2003.

7 J. I. Andrés Ucendo, La fiscalidad en Castilla en el siglo XVII: los servicios de millones, 1601-1700, Bilbao, Universidad del País Vasco, 1999. Sobre la evolución de la representación en cortes castellanas existe una abundante bibliografía; señalemos entre las últimas aportaciones, J. I. Fortea Pérez, Las Cortes de Castilla y León bajo los Austrias. Una interpretación, Valladolid, Junta de Castilla y León, 2008, que recoge trabajos anteriores; y F. Lorenzana de la Puente, La representación política en el Antiguo Régimen: las Cortes de 
cualquier otro instrumento contractual entre el soberano y una parte más o menos extensa del cuerpo social. A este segundo supuesto, que en última instancia se fundamenta en la capacidad legitimadora del monarca $^{8}$, responden la figura del donativo, que a pesar de surgir teóricamente en un ofrecimiento espontáneo y amoroso de los súbditos, su empleo creció durante la segunda mitad del siglo XVII incluso en los territorios americanos ${ }^{9}$; las diversas formas de enajenación del patrimonio regio — vasallos, tierras, rentas u oficios-; y los cambios jurisdiccionales, como sucedía con la obtención de un privilegio de villazgo. Estas vías implicaban una fiscalidad tolerada, cuando no abiertamente demandada, en sociedades jerarquizadas en torno a la distinción/privilegio de sus miembros, conscientes de la constante devaluación de su capital simbólico ${ }^{10}$.

Aunque la explotación del recurso de la venalidad como instrumento recaudador de fondos para la hacienda real comenzó a adquirir unas considerables magnitudes desde el siglo XVI, lógicamente en paralelo a los gastos que ocasionaba la política imperial, sus cotas siguieron elevándose en las décadas posteriores -1630-1640 —, para mantenerse aún muy elevadas en la centuria siguiente. Pese a que ya se dispone de significativos estudios sobre importantes parcelas de esta España en almoneda para los siglos modernos —señoríos ${ }^{11}$, títulos nobiliarios ${ }^{12}$, hábitos de órdenes militares ${ }^{13}$ u oficios municipales ${ }^{14}$-, todavía hoy conocemos de forma irregular otros aspectos del mismo fenómeno de enajenación del patrimonio regio, como es el caso de los privilegios de villazgo a aquellas aldeas que pretendían segregarse de su cabeza de jurisdicción, ya fuese ésta otra villa o una ciudad, a cambio de la satisfacción de un servicio monetario a la hacienda real. Es cierto que en esta percepción general hay que hacer salvedad de la obra de Helen Nader,

Castilla, 1655-1834, Madrid, Congreso de los Diputados, 2013.

8 A. M. Hespanha, "Paradigmes de légitimation, aires de gouvernement, traitement administratif et agents de I' administration", en R. Descimon, J. F. Schaub y B. Vincent (dirs.), Les figures de l'adminstrateur. Institutions, réseaux, pouvoirs en Espagne, en France et au Portugal, 16 $16^{e} 19^{e}$ siècle, París, École des Hautes Études en Sciences Sociales, 1997, pp. 19-28.

9 J. I. Fortea Pérez, "Impuestos, servicios, arbitrios y donativos en la Castilla moderna: una fiscalidad de geometría variable", en Historia en fragmentos: estudios en homenaje a Pablo Fernández Albaladejo, Madrid, UAM, 2017, pp. 79-102; y R. Lanza García, "El donativo de 1629 en la Andalucía bética", Studia historica. Historia Moderna, 32, (2010), pp. 179-227; el caso americano en L. De Nardi, "Los donativos voluntarios", América Latina en la Historia Económica, 25/1 (2018), pp. 7-35.

10 En general, E. Soria Mesa, La nobleza en la España moderna: cambio y continuidad, Madrid, Marcial Pons, 2007.

11 A. Marcos Martín, De esclavos a señores. Estudios de Historia Moderna, Valladolid, Universidad, 1992, pp. 235-312; E. Soria Mesa, La venta de señoríos en el reino de Granada bajo los Austrias, Granada, Universidad de Granada, 1995; y G. Lemeunier, Los señoríos murcianos: s. XVI-XVIII, Murcia, Universidad, 1998.

12 M. M. Felices de la Fuente, La nueva nobleza titulada de España y América en el siglo XVIII (1701-1746): entre el mérito y la venalidad, Almería, Universidad, 2012.

13 D. M. Giménez Carrillo, Los caballeros de las órdenes militares castellanas. Entre Austrias y Borbones, Almería, Universidad, 2016, pp. 106-117.

14 Además de los trabajos pioneros de F. Tomás y Valiente y A. Domínguez Ortiz, interesan los de M. Hernández, "Venalidad de oficios municipales en la Castilla del siglo XVIII. Un ensayo de cuantificación", Chronica Nova, 33, (2007), pp. 95-129; E. Soria Mesa, "Comprando poder: Una aproximación a la venta de oficios en el reino de Granada (ss. XVI y XVII)", e I. A. A. Thompson, "Some observations on Crown sales of municipal offices in Castile, 1640-1665", ambos en A. Marcos Martín (ed.), Hacer historia desde Simancas. Homenaje a José Luis Rodríguez de Diego, Valladolid, Universidad de Valladolid, 2011, pp. 745-762 y 763786; y F. Andújar Castillo y M. M. Felices De la Fuente (coords.), El poder del dinero. Ventas de cargos y honores en el Antiguo Régimen, Madrid, Biblioteca Nueva, 2011. 
Liberty in Absolutist Spain ${ }^{15}$, que ya advertía a principios de los noventa de la necesidad de atender estas voces del mundo rural para comprender el conjunto de la sociedad castellana moderna. Aun así, los trabajos tan dispersos que sobre este recurso pueden encontrase coinciden en la importancia de esta vía en la financiación de la Monarquía ${ }^{16}$, en muchas ocasiones circunscrita al reinado de Felipe IV, momento en el que las urgencias del soberano obligaron a activar cualquier medio que engrasase la maquinaria imperial con la que resistir los continuos desafíos franceses. Sin embargo, la prolongación de los problemas hacendísticos en las décadas posteriores hizo mantener unas fuentes de ingresos heterogéneas, incluida la que se derivaba de la concesión de nuevos villazgos.

En este estado de la cuestión no pretendemos confeccionar una mera nómina de nuevas villas con la que volver a confirmar el déficit crónico del erario hispánico; ni caer, por otro lado, en un relato liberacionista frente al poder opresor de las poblaciones de las que dependían. Por el contrario, lo que queremos apuntar en este trabajo son varios aspectos de este instrumento de la Corona que pensamos no se les han prestado suficiente atención.

En primer lugar, el significado que poseía la adquisición de un villazgo en la cultura política de la Castilla moderna. En una sociedad corporativa, jerárquicamente estructurada, la compra de un privilegio de villazgo y la instauración de un regimiento segregado, servía idealmente para satisfacer la aspiración al honor de la nueva corporación, para subrayar la autoridad de sus órganos rectores, fundamentar el buen gobierno de la comunidad y asegurar su autonomía para servir al rey sin dependencia de ningún poder intermedio. En este sentido, los villazgos venían a demostrar la dinámica política que se generaba en el interior de los propios lugares, así como la percepción que sus vecinos podían poseer de los ritmos y funcionamiento de la Monarquía, a los que adaptaban sus estrategias emancipadoras.

En segundo lugar, la ficción del discurso anti señorial que se encubría tras las peticiones de villazgo: en la mayoría de las ocasiones éstas se elevaban al monarca por unos entramados proto-oligárquicos que participaban débilmente en las instituciones municipales de sus respectivas sedes jurisdiccionales, motivo por el que trataban de crear concejos de nueva planta en los que reproducir precisamente un control similar del poder local. Por esto mismo, no nos debe extrañar que los protagonistas de estos procesos

15 Liberty in absolutist Spain: the Habsburg sale of towns, 1516-1700, Baltimore, Johns Hopkins University Press, 1990.

16 A. Palomeque Torres, "El señorío de Valdepusa y la concesión de un privilegio de villazgo al lugar de Navalmoral de Pusa en 1635", Anuario de Historia del Derecho Español, XVII, (1946), pp. 140-228; A. Domínguez Ortiz, "La ruina de la aldea castellana", Revista Internacional de Sociología, 6, (1949), pp. 99124; A. Domínguez Ortiz, "Ventas y exenciones de lugares durante el reinado de Felipe IV", Anuario de Historia del Derecho Español, LXXXVII, (1964), pp. 163-208; J. Cano Valero, "Intentos frustrados de villazgo y exención jurisdiccional del lugar de Villamalea en el siglo XVII", Al-basit, 13, (1984), pp. 25-36; E. Soria Mesa, "La ruptura del orden jurisdiccional en la Castilla de los Austrias. Una interpretación a la luz del poder local", Cuadernos del Seminario Floridablanca, 4, (2001), pp. 439-458; V. Montojo Montojo, "Las ciudades contra sus aldeas. El estatuto de los lugares en el Reino de Murcia (ss. XV-XVIII)", Murgetana, 106, (2002), pp. 17-35; M. Á. Faya Díaz, "La venta de señoríos eclesiásticos de Castilla y León en el siglo XVI", Boletín de la Real Academia de la Historia, CC/II, (2003), pp. 101-132; A. Marcos Martín, "La justicia también se vende. Algunas consideraciones sobre las ventas de jurisdicción en la Castilla de los siglos XVI y XVII", en J.L. Castellano y M.L. López-Guadalupe (coords.), Homenaje a don Antonio Domínguez Ortiz, Granada, Universidad de Granada, 2008, vol. 2, pp. 469-486, así como "Porque siendo Villa y teniendo jurisdicción por sí vendrá [Mazarrón] a aumentarse y ser pueblo muy grande... Exenciones de lugares y concesiones de villazgos en Castilla en el siglo XVI", en J. J. Ruiz Ibáñez y M. Campillo Méndez (coords.): Felipe II y Almazarrón: la construcción local de un Imperio global, Murcia, Universidad de Murcia, vol. 2, 2014, pp. 27-49; y J. E. Gelabert, "Señoras de sí mismas. La constitución de villas en la España del Antiguo Régimen", en Jarque Martínez, E. (coord.): El concejo en la Edad Moderna: poder y gestión de un mundo en pequeño, Zaragoza, P.U.Z., 2016, pp. 15-42. 
de separación procedan fundamentalmente de aquellos labradores propietarios que adquirieron una ventajosa posición económica dentro de la aldea, pero que distaban de encontrar un efectivo reconocimiento social en el ámbito político del que formaban parte ${ }^{17}$; individuos -o familias- que en muchos casos estaban inmersos, además, en procesos de acumulación de capital simbólico que los igualasen o superasen a otros convecinos con los que competían en expectativas de movilidad social. Aunque son dignos de atender los discursos para legitimar los derechos a estas solicitudes, repletos de descripciones de los supuestos actos violentos de los que eran víctimas, con frecuencia estos topoi no sirvieron más que para disimular la consolidación social y las expectativas de beneficio que abrigaban unas élites en construcción en sus respectivos ámbitos territoriales. Para ellas, convertirse en las nuevas rectoras de la comunidad sí les ofrecía la posibilidad de alcanzar mayores cotas de autogobierno y libertad.

En tercer lugar, también nos proponemos comprobar cómo la Corona extrajo rentabilidad política de estos deseos procedentes de la base del sistema de dominación monárquico a través de la concesión de este arbitrio real. Al igual que ocurría con cualquier tipo de oficio, renta o título nobiliario enajenado por la Corona, estas cartas de libertad resultaban no sólo un ingreso económico directo, sino también una ampliación de sus agentes intermediarios y un desarrollo de los mecanismos de reciprocidad sobre los que se asentaba el sistema político. Esas nuevas élites locales se veían impelidas a mantener su relación servicial con el soberano por cuanto necesitaban seguir incrementando su capital simbólico, si no querían quedar rezagados en un espacio político castellano susceptible de devaluarse. Por tanto, el intenso mercado de villazgos existente en la Castilla del Seiscientos ${ }^{18}$, lejos de entenderse como una merma en la autoridad del rey, conllevaba un instrumento de actualización de sus vínculos con los grupos de poderosos locales y una forma de movilizarlos en apoyo de su política fiscal.

Para contextualizar estas tres hipótesis que proponemos, tomaremos la casuística que representa el reino de Murcia durante la segunda mitad del siglo XVII, un territorio que contaba desde la conquista cristiana con un número limitado de concejos, en su mayoría con un amplio alfoz y una población que solía estar concentrada en la cabecera municipal ${ }^{19}$. Los seis casos de fundación de villas ex novo durante este periodo pueden tomarse como un indicador, más o menos orientativo, de la extensión que pudo alcanzar este recurso fiscal para toda Castilla a lo largo del reinado de Carlos II, así como el grado de desarrollo socioeconómico que alcanzaron estos pequeños grupos de poder en sus respectivos ámbitos territoriales. Las necesidades permanentes de la guerra contra Francia agravaron un crónico déficit hacendístico que promovía todo este sistema de enajenación del patrimonio regio con figuras fiscales, como el villazgo, que hasta ahora parecían más relegadas con el último de los Austrias desde $1670^{20}$. Sin embargo, en la corte del último Austria cualquier posibilidad de ingresos era bien recibida, si con ello se contribuía a la

17 Esta demanda de oficios en F. J. Aranda Pérez, "Un reino de repúblicas: comunidades políticas ciudadanooligárquicas y su representación en la Castilla Moderna", en M. Á. Faya Díaz (coord.), Las ciudades españolas en la Edad Moderna: oligarquías urbanas y gobierno municipal, Oviedo, KRK, 2014, pp. 23-62; y M. López Díaz, "Espacios y redes de sociabilidad de las oligarquías urbanas en la Galicia moderna: avances y propuestas de estudio", Obradoiro de Historia Moderna, 23, (2014), pp. 139-173.

18 H. Nader, Liberty in absolutist Spain..., pp. 119-129, donde se ofrece una aproximación cuantitativa.

19 M. T. Pérez Picazo y G. Lemeunier, El proceso de modernización de la región murciana (siglos XVI-XIX), Murcia, Editora Regional, 1984, pp. 24-167.

20 H. Nader, Liberty in absolutist Spain..., p. 127. A esta percepción responde probablemente el escaso eco que los villazgos tienen en el magnífico panorama general ofrecido en J.A. Sánchez Belén, La política fiscal en Castilla durante el reinado de Carlos II, Madrid, Siglo XXI, 1996, pp. 311-314. 
resistencia agónica de una Monarquía amenazada en los escenarios de guerra de Flandes, del Mediterráneo o de más allá del Océano ${ }^{21}$.

\section{LA REDEFINICIÓN JURISDICCIONAL DE UN REINO PERIFÉRICO}

Aprovechando las inmensas jurisdicciones que poseían los concejos castellanos meridionales, como consecuencia del modelo de repoblamiento cristiano, la Corona otorgó la venta de gran número de lugares a la propia población o a individuos particulares especialmente en momentos de extrema necesidad. Aunque el concejo de Murcia consiguió eludir la tentativa de exención de Fuente Álamo en $1632^{22}$, en una época en la que pocas ciudades consiguieron evadirse a este tipo de enajenaciones ${ }^{23}$, su experiencia también contaba con fracasos recientes -caso del villazgo de Fortuna (1628)- a su resistencia de ver reducido su espacio municipal. No faltaron localidades castellanas que trataron de evitar estos proyectos emancipadores comprando a la propia Corona su término, pero, como en el caso de la villa murciana de Cehegín ${ }^{24}$, tampoco esta táctica jurídica aseguró los resultados esperados ante las ansias recaudatorias del monarca.

La venta de villazgos prosiguió dentro de un proceso general de enajenaciones del patrimonio regio que no se redujo sólo a la formación de pequeños señoríos durante el segundo cuarto del Seiscientos -Buznegra, Espinardo, Hoya Morena, La Alberca, Roldán, Santa Cruz de la Ribera-, sino que se extendió a otros cambios jurisdiccionales que demandaban las oligarquías locales. Ese fue el caso de la segregación del corregimiento de Lorca (1645), Hellín (1665) o la división del que formaban las ciudades de Chinchilla y Villena (1690), así como la creación de una subprovincia fiscal para los territorios de la Orden de Santiago 25 .

Entre 1665 y 1700, la Cámara de Castilla concedería en el reino de Murcia seis privilegios de villazgo, muchos más de los otorgados en el resto de siglo -únicamente dos en 1628, Fortuna, y en 1630, La Roda- y en conjunto una cantidad más parecida a los consignados por Felipe II, el primer gran momento de venta del patrimonio real. Se trataba de las nuevas villas de Huércal-Overa (1668), antigua aldea del extensísimo término de la ciudad de Lorca, aunque desde 1833 integrado en la provincia de Almería; Fuensanta (1671), lugar de la villa de La Roda, en el límite septentrional del reino, pero incluido en el partido fiscal de San Clemente; Nerpio (1688), perteneciente a Yeste, dentro de los territorios de la orden de Santiago, muy cerca de la nueva villa de Santiago de la Espada (1691), dependiente de Segura de la Sierra; Bullas (1689), que se desgajaría de la linajuda villa de Cehegín, también encomienda santiaguista; y, por último, Fuente Álamo (1700), cuya vida independiente apenas duraría un par de años (1702) ante las presiones de sus poderosas localidades vecinas.

21 Ch. Storrs, The Resilience of the Spanish Monarchy 1665-1700, Oxford, Universidad, 2006 [ed. en español, Madrid, 2013], y Espino López, A., Fronteras de las monarquía. Guerra y decadencia en tiempos de Carlos II, Lleida, Milenio, 2019.

22 Archivo Municipal de Murcia (AMM), legajo (leg.) 1.021.

23 Alicante consiguió la reversión de Muchamiel (villa en 1628-1653), San Juan y Benimagrell (universidad en 1593-1614; fracasó de nuevo San Juan en 1645): M. Díez Sánchez, La hacienda municipal de Alicante en la segunda mitad del siglo XVII, Alicante, Institución Juan Gil-Albert, 1999, p. 90, nota 123.

24 Archivo General de Simancas (AGS), Cámara de Castilla (CC), leg. 2.068: Madrid, 6.8.1690: memorial de Cehegín al rey.

25 J. J. Ruiz Ibáñez, Las dos caras de Jano. Monarquía, ciudad e individuo. Murcia, 1588-1648, Murcia, Universidad de Murcia, 1995, pp. 60 y 297-298; y S. Molina Puche, Poder y familia. Las élites locales del corregimiento Chinchilla-Villena en el siglo del Barroco, Murcia, Universidad, 2007, pp. 21-40. 
Gráfico 1. Evolución del número de villazgos en el Reino de Murcia (siglos XVI-XVIII)

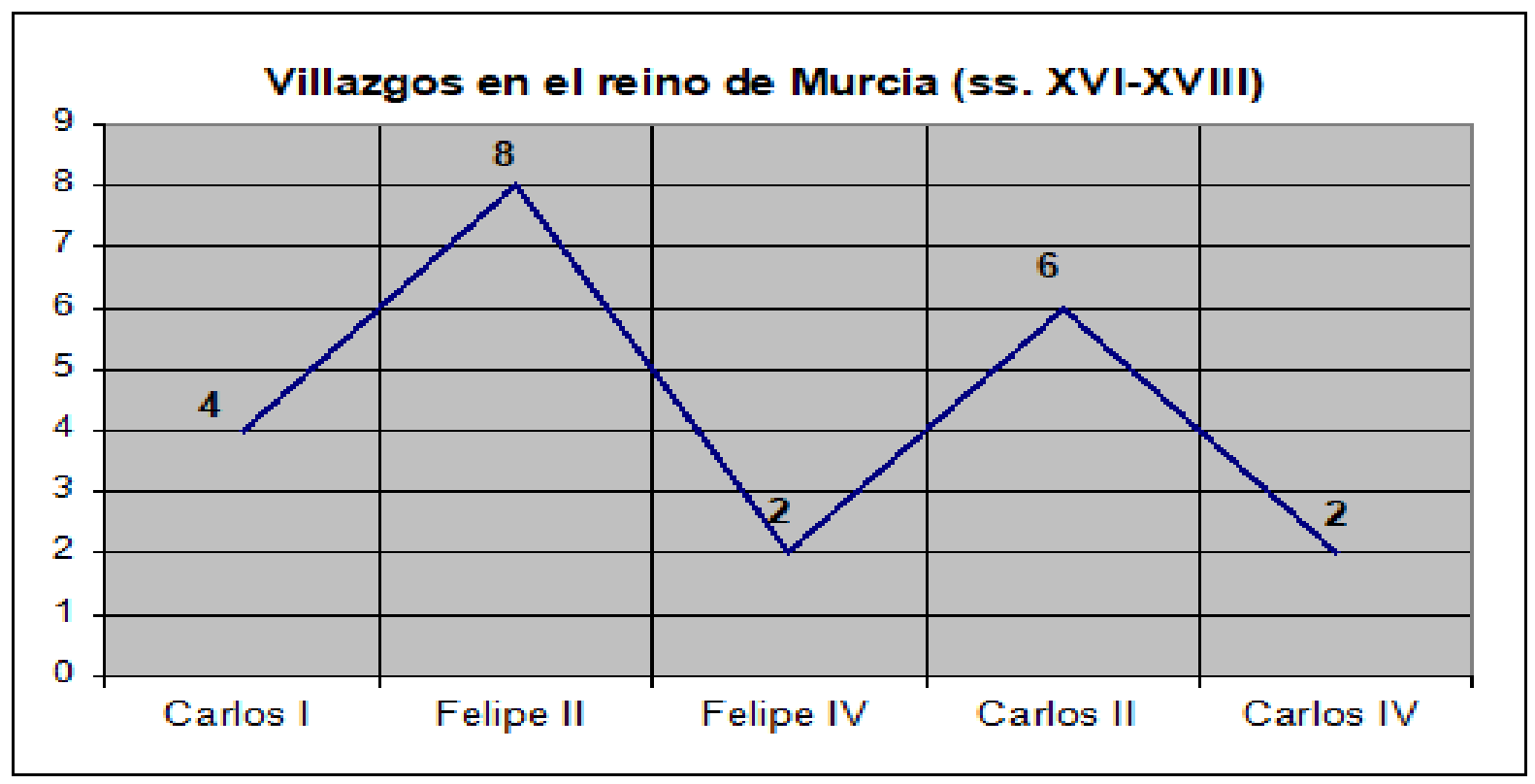

Fuente: Archivo General de Simancas, Consejo de Hacienda, Expedientes de ventas de villazgos. Carlos I: Villarrodrigo, Genave, La Gineta y Torres de Albánchez (1551-1554). Felipe II: Abarán, Blanca, Ojós, Ricote, Villanueva de Segura, Alguazas (1581), Mazarrón (1565) y Alpera (1566). Felipe IV: Fortuna (1628). Carlos II: Huércal Overa (1668), Fuensanta (1671), Nerpio (1688), Bullas (1689), Santiago de la Espada (1691) y

Fuente Álamo (1700). Carlos IV: Totana (1795) y Águilas (1798).

Este número tan significativo de villazgos durante el reinado de Carlos II viene dado obviamente por las necesidades hacendísticas del soberano, pero también hunde sus raíces en fenómenos sociales de origen exclusivamente regional y local. La coyuntura económica de las últimas décadas del siglo XVII constituyen en el reino de Murcia un momento de recuperación de los años más críticos de la centuria, lo que permitió no sólo a los poderosos locales fundar extensos mayorazgos, sino también, en la escala micro que suponían las aldeas, invertir en la independencia de sus lugares ${ }^{26}$. Si en unos casos el mayorazgo constituía un capital simbólico que permitía alcanzar a una familia nuevos privilegios demandados por la sociedad castellana -hábitos, encomiendas, títulos u oficios-, en los otros casos el villazgo podía dar comienzo a carreras basadas en el ejercicio de regidurías y el desempeño de todo tipo de servicios a los monarcas. Siendo los medios y los fines similares en ambos supuestos, las diferencias venían dadas por el diferente grado de desarrollo de unas dinámicas sociales que se hallaban interiorizadas entre los castellanos del Barroco.

No obstante, la lucha por la emancipación de las aldeas no solía ser nada fácil ${ }^{27}$. La resistencia de las ciudades y villas cabeceras ante los órganos sinodales encargados de estos procesos era frecuente, porque la desmembración de parte de sus términos implicaba la disminución de habitantes, rentas y, en general, recursos económicos. Es por esta razón por la que algunos de estos villazgos tendrían corta vida ante las presiones de sus poderosos vecinos, y algunos otros tuvieron que pleitear durante años hasta ver confirmado su carácter

26 El contexto de esta coyuntura en J. D. Muñoz Rodríguez, La séptima corona. El Reino de Murcia y la construcción de la lealtad castellana en la Guerra de Sucesión (1680-1725), Murcia, Universidad de Murcia, 2014, cap. 1.

27 Ese fue el caso de Linares con respecto a Baeza: H. Nader, Liberty in absolutist Spain..., pp. 130-154. 
de "villa de sí y sobre sí"; mas, en casi todos los casos, los intérpretes de estas poblaciones rurales, las oligarquías que se estaban conformando, percibieron que para hacer realidad sus alegatos libertadores en una corte cada vez más compleja habrían de disponer de influyentes valedores que compensasen la férrea oposición de las villas o ciudades de las que pretendían eximirse ${ }^{28}$. Así lo entendieron los vecinos de Nerpio, uno de los villazgos que a continuación trataremos; en el memorial presentado a la Cámara de Castilla se adjunta una carta de don Ginés Pérez de Meca, presidente del consejo de Hacienda y miembro destacado de la élite de la ciudad de Lorca, dirigida a don Juan Terán y Monjaraz, secretario del registro general de mercedes, en la que le expresaba su patrocinio a la pretensión de estos vecinos ${ }^{29}$. Aunque no es muy usual encontrar evidencias tan incontestables de estas relaciones políticas informales, lo cierto era que el éxito de cualquier demanda ante los tribunales cortesanos no prosperaba con rapidez si no mediaban estos factores de mercedes entre los círculos del poder.

\section{CARLOS II, PADRE DE NUEVAS REPÚBLICAS}

El consejo de Hacienda vendió señoríos y villazgos a pesar de que, teóricamente, no era partidario de que continuasen sus ventas, pues sobrecargaban a la población en un período de política fiscal proclive precisamente al alivio de las cargas tributarias ${ }^{30}$. El órgano supremo en materia hacendística no incrementó las alcabalas y los millones bajo Carlos II, como hizo en el reinado de su padre, sino prorrogó los servicios concedidos en la última convocatoria en 1658, ya que de lo contrario se hubiera visto obligado a convocar Cortes, situación que evitó a pesar de las insistentes peticiones de algunos regidores de ciudades con voto ${ }^{31}$. Así pues, aunque no hubo aumento de la presión fiscal a través de esas figuras, sí recurrió a otro tipo de arbitrios, como fue la venta de jurisdicciones -demandadas por las élites locales-, los donativos y la monetarización del servicio de milicias, hasta entonces de carácter personal ${ }^{32}$.

La población de Fuente Álamo de Murcia fue un ejemplo del aprovechamiento de las peticiones de villazgos como recurso fiscal. En la correspondencia de 1700 del concejo de Murcia con su agente de negocios en Madrid, se señala que "[...] esto mismo [la venta de villazgos a los lugares] sucede en todas las ciudades que no tienen compradas las jurisdicciones, como ha sucedido en Córdoba o Málaga y en otras partes estos próximos años, en que se han eximido infinitos lugares sin hacer estimación estos señores de ellos y sólo reparan en si hay o no privilegio de compra para no eximir, porque ya entonces no está la jurisdicción en precario"33. La exención de lugares fue para el rey un medio financiero

28 J. J. Ruiz Ibáñez y J.D. Muñoz Rodríguez, "Sirviendo a la Corte en la aldea, sirviendo a la aldea en la Corte: Veteranos, agentes y medios de relación en el siglo XVII castellano", en Espacios de poder: cortes, ciudades y villas, Vol. 2, Madrid, Universidad Autónoma de Madrid, 2002, pp. 227-247.

29 AGS, CC, 1.511: Madrid, 14.6.1688: la población de Nerpio; la carta lleva fecha de 11 de junio y la escritura de villazgo de 28 de junio de ese mismo año.

30 J. A. Sánchez Belén, "La Junta de Alivios de 1669 y las primeras reformas", Espacio, Tiempo y Forma, 4/4, (1989), pp. 639-668, cfr. 664.

31 Algunos ejemplos en: I. A. A. Thompson, "Conflictos políticos en las ciudades castellanas en el siglo XVII", en J. I. Fortea Pérez, y J. E. Gelabert González (coords.), Ciudades en conflicto: (siglos XVI-XVIII), Santander, Universidad de Cantabria, 2008, pp. 37-56; y J. D. Muñoz Rodríguez, “¿Divide ut regnes?: Representación e integración del Reino en la Corona de Castilla (1665-1700)" en J. Sobrequés y otros (coords.), Actes del 53 Congrés de la Comissió Internacional per a l'estudi de la Història de les Institucions representatives $i$ parlamentàries, vol. I, Barcelona, Partament de Catalunya, 2005, pp. 257-263.

32 J. I. Andrés Ucendo y R. Lanza García, "Estructura y evolución de los ingresos de la Real Hacienda de Castilla en el siglo XVII", Studia histórica. Historia Moderna, 30, (2008), pp. 147-190.

33 AMM, leg. 3.760: Madrid, 3.7.1700: carta de don Antonio Belvís del Castillo a la Ciudad de Murcia. 
más, al que sólo pudo detener la contraprestación de otra fuente de financiación alternativa, fuera la concesión del privilegio de no exención o el derecho de tanteo.

La situación administrativa de las aldeas implicaba un problema polémico y virulento en el conjunto del reino y, sobre todo, en ciudades como Murcia y Lorca o en villas como Cehegín y Yeste, que tuvieron varios lugares dependientes con deseos de separarse, aunque, en general, se dejó sentir en otros muchos territorios castellanos. Las poblaciones cabeceras rehusaron reconocer más entidad a sus aldeas que la de lugares, a las que solían llamar cortijos o calles y en donde nombraban alcaldes o diputados con carácter ejecutivo, pero sin ninguna función judicial ${ }^{34}$. Al mismo tiempo, trataron de minimizar su entidad eclesiástica con el fin de que no sirviese como justificación de una posible emancipación posterior. En el caso de Fuente Álamo se llegó, incluso, a que el concejo de la capital negara su dezmatorio, que sólo afectaba a la parte de Lorca, y su alcabalatorio, que aunaba las tres jurisdicciones de quienes dependía 35 .

Las resistencias de las poblaciones cabeceras no paraban ahí. Concedida la jurisdicción a Fortuna (1628) y a Fuente Álamo (1700), Murcia hizo todo lo posible para recuperar la justicia criminal y dejarles sólo la civil, con la excusa de que los nuevos villazgos, como los señoríos del reinado de Felipe IV, eran refugios de malhechores por su cercanía con la frontera del reino de Valencia, justificación -el hecho fronterizo- que también había empleado Fuenterrabía con Irún para evitar su segregación ${ }^{36}$.

\subsection{Huércal y Overa (1668)}

Huércal-Overa, una de las aldeas del extenso término de la ciudad de Lorca, fue la primera en conseguir su villazgo en julio de 1668. Contaba en ese momento con 120 vecinos y era el centro de un amplio espacio que, desde los tiempos nazaríes, se empleaba para la invernada de los ganados de Guadix y la Hoya de Baza; el fin de la frontera granadina no modificaría esta realidad económica, sino que incrementaría los intereses ganaderos por estos pastos situados entre las poderosas ciudades de Lorca y Vera, y los estados del marqués de los Vélez, adelantado y capitán mayor del reino de Murcia ${ }^{37}$. Ya en el siglo XVII, los mercaderes genoveses de lanas apreciarían las posibilidades comerciales de esta zona, desarrollando tal control sobre el mismo que uno de ellos, don Juan Bautista Montanaro, vecino de Cartagena, sería nombrado en 1708 por el archiduque Carlos de Austria marqués de Huércal-Overa ${ }^{38}$.

Así pues, en la emancipación municipal de este territorio estratégicamente situado entre los reinos de Murcia y Granada no serían ajenos los amplios intereses mercantiles que por entonces se estaban construyendo. Su venta continuaba la práctica del reinado de Felipe IV de ventas de vasallos, cuya autorización habían otorgado con grandes reticencias

34 L. Buendía Porras y J. D. Muñoz Rodríguez, "Nuevos poderes para nuevos espacios. Los diputados de la marina murciana en la vertebración política del territorio (ss.XVII-XVIII)", Murgetana, 107, 2002, pp. 73-91.

35 Archivo del Cabildo Catedralicio de Murcia (ACM), caja G 15, nn. 486 y 501.

36 S. Truchuelo García, "Irún y Hondarribia: una controvertida historia de discrepancias y consensos", Boletín de Estudios del Bidasoa, 29, (2017), pp. 83-102.

37 Para el periodo bajomedieval, J. F. Jiménez Alcázar, Huércal y Overa: de enclaves nazaríes a villas cristianas (1244-1571), Huércal-Overa, Ayuntamiento, 1996.

38 V. Montojo Montojo y F. Maestre de San Juan-Pelegrín, "Las relaciones comerciales entre el Reino de Granada y el Reino de Murcia en la Edad Moderna", en M. Barrios Aguilera y Á. Galán Sánchez (coords.), La historia del reino de Granada a debate: viejos y nuevos temas, perspectivas de estudio, Madrid, Editorial Actas, 2004, pp. 281-303; y del primero, "Los comerciantes de Alicante y Cartagena en la Guerra de Sucesión", Estudis, 34, (2008) pp. 219-239. También: R.M. Girón Pascual, Las Indias de Génova. Mercaderes genoveses en el reino de Granada durante la Edad Moderna (ss. XVI-XVIII), Granada, Universidad de Granada, Tesis doctoral, 2013. 
las Cortes de 1625-1630 para obtener ingresos económicos con los que sufragar los gastos de la Monarquía ${ }^{39}$.

La venta de Huércal-Overa se hizo en régimen de factoría, es decir, el beneficio se aplicaba para pagar a uno o varios asentistas que habían prestado grandes sumas de dinero a la Corona para atender gastos perentorios ocasionados por las guerras de Portugal y de Devolución entre 1665 y 1668. Aunque estaba estipulado el precio por el consejo de Hacienda en 6.200 ducados la legua de territorio, además de la media anata de la merced ${ }^{40}$, la enajenación de esta aldea se efectuó por error en 5.600 ducados la legua, cantidad que el propio órgano hacendístico trató de solventar posteriormente. No obstante, los vecinos pagaron finalmente más de lo estipulado en un principio, puesto que tuvieron que hacer frente al censo pedido sobre los bienes de propios -su codiciada zona de pastos- para satisfacer el capital principal.

Tampoco fue sencillo el amojonamiento de la nueva villa, ya que la propia ciudad de Lorca denunció la violencia con la que se realizó y la parcialidad con la que actuó el juez de comisión enviado por la Cámara de Castilla: le acusaba de no respetar los deslindes que se hacían desde finales del siglo XVI, al permitir las demandas de los representantes de la nueva villa y perjudicando hasta en tres cuartos de legua el término lorquino ${ }^{41}$.

Para los vecinos de Huércal-Overa, su villazgo y la compra de los oficios concejiles provocó un alto endeudamiento de la hacienda local, de manera que el nuevo ayuntamiento todavía debía a mediados del siglo XVIII una gran suma de dinero por el acceso a su ansiada libertad municipal ${ }^{42}$.

\subsection{Fuensanta (1671)}

Era una población pequeña que no llegaba a los 50 cabezas de familia -45 vecinos, incluyendo en ellos a 5 viudas-, número que se tomaría para la compra al rey en razón de 7.500 maravedíes por cada uno ${ }^{43}$. Estaba situada junto al límite septentrional del reino de Murcia, en medio de la llanura manchega, por lo que su economía dependía de una agricultura de secano de base cerealista, junto a una intensa dedicación ganadera que aprovechaba las importantes vías mesteñas que pasaban por su territorio. Estas actividades económicas lograrían un intenso desarrollo en el último tercio del Seiscientos que permitieron ampliar la población y consolidar algunos patrimonios familiares.

Fuensanta era aldea de La Roda y, aunque había pertenecido al partido de San Clemente y a la diócesis de Cuenca, en 1586 Felipe II la integró en el corregimiento de Chinchilla-Villena, quedando a partir de la división de 1690 dentro del ámbito jurisdiccional de la primera, cuyos titulares actuaban mayormente desde la renovada población de Albacete. Esta dependencia política, que no fiscal, pues se incluía en la superintendencia de San Clemente, pudo favorecer que, desde ese momento, Fuensanta fuese basculando su relación hacia las tierras más meridionales del reino ${ }^{44}$.

39 AGS, DGT, Inventario 24, leg. 464, f. 97: Cédula confirmando su exención de jurisdicción y término y en el nombramiento de diferentes oficios (1668).

40 A. Domínguez Ortiz, Instituciones y sociedad en la España de los Austrias, Madrid, Ariel, 1985, p. 60.

41 Archivo Municipal de Lorca (AML), Ac.Cap. 11.7.1668.

42 AGS, DGT, Inventario 24, leg. 475, f. 320: Madrid, 31.3.1817: Copia de la cédula de S.M. confirmándole su jurisdicción y derecho de nombrar oficios q le pertenece perpetuo por juro de heredad.

43 AGS, CC, leg. 1.983-7: Madrid, 6.7.1671: memorial de los vecinos de Fuensanta al rey. Apenas veinte años después su población había aumentado en más de veinte vecinos (casi un 50\% más): AGS, GA, 2.934: Relaciones del vecindario de la Corona de Castilla para el servicio militar del año 1693.

44 S. Molina Puche, Poder y familia..., p. 25; y para el ámbito fiscal, I. de la Rosa Ferrer, "La Superintendencia General de las Rentas Reales del Marquesado de Villena en el siglo XVII. Análisis institucional" en La 
Además de las urgencias fiscales del monarca, la tramitación y concesión de este villazgo se justificaba en las "molestias y vejaciones" que los moradores alegaban contra la administración de justicia establecida en ese lugar -un alcalde pedáneo-y, sobre todo, en los excesos en el reparto de las rentas reales que se les imponían ${ }^{45}$. Sin embargo, Juan de las Casas, representante de la villa de La Roda, señalaba en su memorial al consejo de Castilla unas circunstancias que ampliaban las razones que encubría este deseo de segregación: además de indicar que "[...] no ha incurrido el consentimiento de todos los vecinos del lugar de Fuensanta", la pretensión decía partir "de tres o cuatro [vecinos] de los más poderosos" que "se han valido del poder y amenazas haciendo en los demás miedo justo y violencia declarada para oprimirlos con mayor servidumbre y hacer más libre su dominación [...]"46. El control del poder político y de la hacienda locales generaba unas expectativas de beneficio entre estos individuos poderosos que alimentaban sus deseos de cambiar su estatus jurisdiccional.

\subsection{Nerpio (1688) y Santiago de la España (1691)}

Parecidos argumentos esgrimieron los vecinos de Nerpio para separarse de la villa de Yeste, encomienda santiaguista en el interior del reino de Murcia, cuyas justicias les infligían, al parecer, "muchas vejaciones y molestias"47. Ya en 1609, después de una rápida colonización de este territorio de la Sierra de Segura durante el siglo XVI, sus moradores habían intentado obtener el villazgo, cuando la población contaba con cerca de 150 familias, de las que trece habían acumulado unos estimables patrimonios gracias a la explotación ganadera, una cierta industria textil de transformación de paños y el desarrollo agrícola producido por los cultivos característicos derivados de la tríada mediterránea ${ }^{48}$.

Sin embargo, la deseada merced se retrasó hasta junio de $1688^{49}$. A cambio de un pago de 7.500 maravedíes por vecino -que se realizaría en tres pagos como estipulaba el contrato de obligación-, el monarca instituyó un concejo en la localidad compuesto por una decena de cargos municipales, así como la prioridad de sus habitantes para obtener en arriendo anual las dehesas de Taibilla por dos mil reales de renta ${ }^{50}$. Pese a mantener ciertos vínculos de dependencia con su antigua localidad, como la eclesiástica con la parroquia de Yeste, los poderosos de Nerpio consiguieron ejercer a partir de entones un mayor control sobre los pastos que daban alimento al importante tráfico ganadero de la comarca ${ }^{51}$.

El ejemplo de Nerpio pronto tuvo eco en otra población cercana de la encomienda de Segura de la Sierra, llamada El Hornillo, La Puebla de Santiago o -como hoy se denomina-

investigación y las fuentes documentales de los archivos, Guadalajara, ANABAD Castilla-La Mancha, 1996, pp. 685-709.

45 AGS, CC, leg. 1.983-7: San Clemente, 20.9.1671: poder de los vecinos de Fuensanta.

46 AGS, CC, leg. 1.983-7: Madrid, 22.10.1671: memorial de Juan de las Casas.

47 La referencia en AGS, Registro General del Sello (RGS), VI (1688): Madrid, 28-VI-1688: merced a la población de Nerpio de eximirla. Existe una copia del villazgo en AMM, 2.016.

48 M. Rodríguez Llopis, "El privilegio de villazgo de Nerpio y su segregación de Yeste", Información Cultural Albacete, 87, 1995, pp. 3-14; y M. Rodríguez Llopis y J. M. Martínez Carrión, "Las transformaciones demográficas de la población rural. Yeste en los siglos XIV al XX", Áreas. Revista de Ciencias Sociales, 3-4 (1983), pp. 13-54.

49 AGS, CC, leg. 1.511: Madrid, 28.6.1688: despacho de concesión del villazgo.

50 AGS, RGS, VI (1688): Madrid, 28-VI-1688: merced a la población de Nerpio.

51 Por ejemplo, Pedro Alfaro, vecino de Nerpio, arrendó el ejido concejil de arriba de Mazarrón, mediante obligación de pago de 600 reales a Ginés Muñoz de Paredes: Archivo Histórico Provincial de Murcia (AHPM), Notarías (Not.) 6.767/38, 19.9.1682. 
Santiago de la Espada, cuyas motivaciones por independizarse de la villa cabecera guardaban mucha similitud con el caso anterior. Después de una intensa repoblación tras la desaparición de la frontera nazarí de Granada, que permitió ocupar un espacio abandonado por los mudéjares, sus habitantes pusieron las bases de una economía dedicada a la ganadería y los recursos del bosque. En las Relaciones Topográficas mandadas confeccionar por Felipe II (1575) se estimaba una población cercana al centenar de vecinos, de los que "[...] hay labradores hasta veinte y habrá señores de ganado hasta catorce [mientras que] todos los demás son gentes de servicio y pobre" 52 .

En 1642, la aldea de El Hornillo o Puebla de Santiago ya había casi triplicado el número de familias -242 vecinos-, destacando la prolongación de su crecimiento demográfico y su desarrollo económico respecto a las localidades de alrededor. No obstante, las décadas centrales de esta centuria conllevarán en toda esta comarca un descenso notable de la población y un retroceso de la actividad ganadera, como consecuencia de epidemias, carestías y una menor demanda de carne en los tradicionales mercados que abastecían; coyuntura que se habría superado para el último tercio de ese siglo ${ }^{53}$. En ese nuevo ciclo expansivo se lograría el villazgo -1691-, constituyéndose el nuevo concejo dentro de la encomienda de Segura de la Sierra ${ }^{54}$.

\subsection{Bullas (1689)}

La emancipación de Bullas fue más larga y costosa que la de Huércal-Overa o Nerpio, pues una vez constituida en villa en 1689 y delimitado su término, Cehegín, a la que había pertenecido hasta entonces, se opuso con todas sus fuerzas: ya lo había hecho en 16141615, cuando Felipe III convirtió ese territorio fugazmente en señorío del regidor don Juan de Ceballos Montefur, inmerso en un proceso de ennoblecimiento con el que pretendía distinguirse dentro del concejo de la capital murciana ${ }^{55}$; lo había hecho a lo largo de esa centuria, presionando a una población de labradores y jornaleros que casi alcanzaba la quinta parte de su propio vecindario ${ }^{56}$; y lo volvería a hacer con violencia en el verano de 1690, cuando sus alcaldes ordinarios se presentaron "[...] con una comitiva de más de cincuenta hombres de armas y entre ellos algunos bandidos" y se llevaron preso al recién nombrado regidor de Bullas, Juan Villagómez, después de destruir los mojones que se habían puesto ${ }^{57}$.

52 C. J. Garrido García y F. Bravo Palomares, "Estudio sociodemográfico de una población de la Sierra de Segura en el siglo XVI: El Hornillo o Puebla de Santiago (Santiago de la Espada)", Boletín del Instituto de Estudios Giennenses, 218 (2018), pp. 89-116.

53 M. Rodríguez Llopis y J. M. Martínez Carrión, “Las transformaciones..., esp. pp. 26-27.

54 Si bien no hemos encontrado ninguna documentación de archivo que acredite este villazgo, esta fecha viene avalada en J. de la Cruz Martínez, Memorias sobre el partido judicial de Segura de la Sierra, Baeza, Imprenta de F. Moreno, 1842, p. 118; y P. Madoz, Diccionario Geográfico-Estadístico-Histórico de España y sus posesiones de Ultramar, tomo XIII. Madrid, Imprenta del Diccionario, 1849, p. 828.

55 AGS, Escribanía Mayor de Rentas, Mercedes y Privilegios, legajo 268, n. 7. No fue el único caso de devolución de señorío, puesto que también le ocurrió a los regidores don Juan Bienvengud de Lizana con Hoya Morena, y a don Juan González de Sepúlveda con Roldán: V. Montojo Montojo, "Señorío y remodelación jurisdiccional y económica en el reino de Murcia: los señoríos de Hoya Morena y Cúllar-Baza (siglo XVII)", Señorío y Feudalismo en la Península Ibérica (siglos XII-XIX), Zaragoza, Institución Fernando el Católico, 1993, pp. 457-473.

56 AGS, GA, 2.934: Relaciones del vecindario de la Corona de Castilla para el servicio militar del año 1693: en ese momento Cehegín contaba con 1107 vecinos frente a los 193 de Bullas.

57 AGS, CC, leg. 2.068: Bullas, 18.8.1690: poder de Bullas al procurador de los reales consejos Antonio Pineda. 
En 1691 el proceso judicial de asignación de término parecía estancado, puesto que Cehegín alegaba que los habitantes de Bullas eran colonos de sus principales hacendados -especialmente las familias Chico de Guzmán, Carreño y Fajardo ${ }^{58}$ - y era imposible señalar los límites de la nueva villa ${ }^{59}$. Bullas, que se descuidó en la contrarréplica y en la nulidad de la delimitación efectuada, consiguió revalidar el amojonamiento de su término en mayo de 1692, para lo que señaló que su jurisdicción correspondía a la dezmería -la zona de recaudación del diezmo eclesiástico- o el ámbito de su misma parroquia ${ }^{60}$.

Desde la concesión de la pila bautismal en 1665, los agravios de los habitantes de Bullas se acumularon contra las autoridades de la villa cabecera: en ese año se llevaron a varios vecinos presos a Cehegín y sólo los redimieron cuando se comprometieron mediante escritura a que "no pedirían exención"; les acusaban del desigual reparto de los servicios fiscales, así como su gravosa recaudación durante el verano, aprovechando el bajo precio del cereal; denunciaban los registros de bienes y haciendas con el fin de cargarles con mayor parte de alcabalas y 4 por ciento, además de los perjuicios que sufrían en la administración de justicia -el desinterés por averiguar los responsables de "tres muertes violentas"-, el abastecimiento de alimentos y en la adjudicación de los alojamientos de tropas de paso ${ }^{61}$. Es cierto que eran quejas frecuentes en la época, fuera en el medio urbano o rural, que se manifestaban incluso en asonadas -Cartagena en $1683^{62}-$, pero en este caso sirvieron para justificar una autonomía que beneficiaba especialmente a los grupos poderosos que se estaban conformando.

Si bien las poderosas familias de Cehegín afirmaban que los habitantes secesionistas actuaban "[...] sin tener los más de ellos bienes raíces en dicho cortijo y paraje, por ser como son labradores de los otorgantes [...]"63, la verdad es que había habitantes con propiedades medianas y bodegas de vino, como era el caso de Juan Fernández, seguramente padre del primer alcalde ordinario Ginés Fernández Sevilla y Espín, asimismo arrendador de los abastos de carne a principios del siglo XVIII'64; Juan de Amor Llorente, uno de los primeros regidores nombrados en la nueva villa ${ }^{65}$; o Antón de Amor Abril, que además de familiar de regidor -primo del anterior-, consiguió hacer licenciado y presbítero a su hijo Damián ${ }^{66}$.

58 F. J. Hidalgo García, Miscelánea Histórica de Cehegín, Cehegín, Ayuntamiento de Cehegín, 2013, pp. 155-165.

59 AGS, CC (procesos y expedientes), leg. 1.983 (folio 7), y 2.056.

60 AGS, CC, leg. 1528: Murcia, 28.5.1692: informe del alcalde mayor de Murcia, don Jerónimo Navarro, sobre sus actuaciones para amojonar de nuevo la villa de Bullas.

61 AGS, CC, leg. 2.068: Bullas, 24.6.1690: copia del villazgo de Bullas (Madrid, 19.12.1689). Estas razones también son tratadas por J. González Castaño, F. Caballero Escribano y M. Muñoz Clares, La villa de Bullas (siglos XVII-XIX): Estudio histórico y socioeconómico, Murcia, AAXS, 1991.

62 J. A. Sánchez Belén y A. Alcaraz Hernández, "Oligarquía municipal e impuestos: La asonada del campo de Cartagena de 1683", Espacio, Tiempo y Forma, 4/4, (1991), pp. 163-202.

63 AHPM, Not. 8.060/69: Cehegín, 22.8.1685, lo que también coincide con el contenido de AGS, CC, leg. 2068: Madrid, 20.9.1690: memorial de la villa de Cehegín. Entre los cehegineros que vivían en Bullas se encontraba don Cristóbal Piñero: AHPM, Not. 9.073/1: Bullas, 20.4.1664: testamento. Sólo se conserva este protocolo notarial de Bullas, que contiene los testamentos de 1664-1685, pues perteneció al distrito notarial de Mula y su archivo fue incendiado en la Guerra Civil.

64 AHPM, Not., 9.073/5: Bullas, 6.5.1664: Juan Fernández declaró las deudas que tuvo por la venta de vino, y señaló que su hacienda en Bullas constaba de "una casa de cuatro cuerpos altos y bajos y el uno de ellos sirve de bodega, en la cual tengo noventa arrobas de vasos de tener vino, algo más o menos, y en dicha partida doce peonadas de viña".

65 AHPM, Not., 9.073/95: Bullas, 2.12.1680: testamento.

66 AHPM, Not., 9.073/107: Bullas, 21.11.1681: testamento de Juana Martínez Corbalán, viuda de Antón 


\subsection{Fuente Álamo (1700)}

Fuente Álamo fue lugar de jurisdicción muy compleja desde el punto de vista civil, pues dependía de las tres grandes ciudades del reino, Murcia, Lorca y Cartagena, pero también desde su vertiente religiosa: su parroquia se formó relativamente pronto -hacia 1582- y fue acabada en 1621, pero no poseía beneficios eclesiásticos, por lo que carecía de una consideración canónica plena ${ }^{67}$. La población intentó constituirse repetidas veces en villa, quizá en 1632 y seguramente en 1665 y 1667 -denegado por disponer la ciudad de Murcia de la concesión de su término por condiciones de servicios ${ }^{68}$, pero sólo lo logró en 1700 , cuando alcanzó los 200 vecinos $^{69}$, para perder ese estatus dos años más tarde. Ante este cierto caos administrativo, que se hacía más gravoso por cuanto la población incrementaba sus expectativas de autonomía, las tres ciudades acordaron en 1696, paralelamente a las petición formal de villazgo, que el lugar estuviese bajo la autoridad de un solo alcalde pedáneo a elegir anualmente por turno, con funciones judiciales y de rendición de cuentas de las rentas reales, así como un término de media legua de circunferencia ${ }^{70}$.

Al ser sus vecinos ganaderos, pastores, labradores y jornaleros, casi todos pecheros, la llegada de nuevos hidalgos motivaba una rápida contestación social, como sucedió en 1603 con Francisco Fernández de Alarcón y en 1635 con José León ${ }^{71}$. La oposición de los habitantes a que se instalasen nuevos hidalgos en el territorio alimentaba las demandas de convertirse en villa, pretensión a la que se negaban las tres poderosas ciudades.

Los alojamientos de soldados también fueron otro foco de problemas. Como hemos visto en otros casos, los vecinos se quejaban de que las ciudades de Murcia, Lorca y Cartagena los sobrecargaban con un número excesivo de soldados, al igual que ocurría con los repartos fiscales -servicio de millones-, en ambos casos en clara desventaja con el resto de habitantes de sus respectivas jurisdicciones. Tampoco fue bien recibida la obligación de levantar en 1673 una compañía local de milicia, seguramente por los gastos que implicaban -armas y dedicación en los alardes- a los individuos movilizados, pero este instrumento de defensa se hizo indispensable para lograr una cierta seguridad en ese sector de la costa y el resguardo de la propia ciudad de Cartagena durante el último tercio del siglo XVII2.

La unificación y emancipación del lugar se presentaba, por consiguiente, como un alivio de sus habitantes. Las gestiones se intensificaron desde 1694, al apoderar a don Gregorio Reillo Hernández para representarlos ante los tribunales cortesanos con la condición de que los nuevos oficios municipales debían ser anuales y no perpetuos ${ }^{73}$; individuo que, además

\section{Amor Abril.}

67 R. Ortega Merino, Fuente Álamo: Apuntes históricos, Murcia, ed. propia, 1947, p. 9; y Archivo Diocesano de Murcia (ADM), legajo 8, n. 10.

68 En 1665 hubo oposición por parte de algunos moradores de la zona de Cartagena contra los de Lorca y algunos otros de Cartagena, que querían ascender a villa: AHPM, Not. 5.436/329 y 345. AMM, caja 27, n. 28 : Real Provisión de 10 de noviembre de 1667, de la reina Mariana de Austria.

69 AGS, GA, leg. 2934: Relaciones del vecindario de la Corona de Castilla para el servicio militar del año 1693.

70 AMC, Ac.Cap. 1696-1701, 19-5-1696, f. 29-30 y AMM, Ac.Cap. 27.4.1696.

71 Archivo de la Real Chancillería de Granada (ARChG), cabina 303, legajo 486, n. 1, 1604; y AMC, Ac.Cap. 1633-1635, 9, 10 y 11.2.1635, fols. 524r-529v.

72 AMM, Ac.Cap. 4-10-1637; y AMC, Ac.Cap. 21.1.1673. Sobre la defensa de la costa murciana en este periodo finisecular, J. D. Muñoz Rodríguez, "Torres sin defensa, defensa sin torres. Las fortificaciones en el resguardo de la costa murciana a finales del siglo XVII", en Actas $V$ Jornadas sobre fortificaciones, piratería $y$ corsarismo en el Mediterráneo, Murcia, Aforca-Ayuntamiento de Cartagena, 2006, pp. 133-151.

73 Archivo Municipal de Fuente Álamo, "Copia del poder notarial conferido a Gregorio Reyllo Hernández a los efectos de obtener la creación de villa, eximiendo a Fuente Álamo de las jurisdicciones de Murcia, Lorca y 
de pertenecer al grupo de familias hidalgas -también Lardín y Miralles- con importantes patrimonios en el lugar, era hermano del regidor de Cartagena don Alonso Hernández Reillo, capitán de milicias y caballero de Santiago, así como cliente del marqués de los Vélez $^{74}$. Para estos poderosos vecinos, la creación de la nueva villa implicaba la posibilidad de ocupar un espacio propio de relación con el rey, a través del cual aumentar el capital simbólico de sus familias.

Del otro lado, la petición formal de villazgo activó la estrategia de las ciudades cabeceras. Se llegó a la concordia de 1696, que implantaba un gobierno único para el lugar ${ }^{75}$; y el regidor de Cartagena don Juan Lorenzo Rato intentó acordar un tanteo económico de los tres concejos que equivaliese al precio pagado por los vecinos. Por su parte, Lorca optó por una vía más violenta al presionar a sus vecinos para que dieran poder en contra de las pretensiones emancipadoras ${ }^{76}$.

Todo fue en vano. En 1700 Fuente Álamo obtuvo su exención jurisdiccional a costa de un esfuerzo económico importante de sus vecinos que asumieron diversos censos consignativos $^{77}$, a cambio de un término municipal que pudo ser parecido al obtenido en $1812^{78}$. La nueva villa pronto despertó la más aguerrida oposición de sus ciudades vecinas, que consiguieron en dos años (1702) la supresión del villazgo ${ }^{79}$. Para este objetivo se sirvieron de la división de los moradores de alguna de sus zonas, como los de El Estrecho, Merino, Balsapintada, Lobosillo y El Espinar -jurisdicción de Murcia-, dirigidos por Francisco Pedreño y Antonio Sánchez, que se quejaron del repartimiento con el que se les gravó para obtener la compra del villazgo ${ }^{80}$. También surgieron problemas entre el nuevo concejo de Fuente Álamo con el cercano de Mazarrón, pues se quejaba de que ésta le redujo su término al modificar el primer amojonamiento efectuado. Por último, tampoco ayudó el absentismo de algunas familias hidalgas -Torres, Fernández de Santo Domingo, García de Cáceres y Hernández Reillo-, que se habían integrado en las ciudades de las que dependía el lugar.

Tras la reincorporación de la villa a sus ciudades cabeceras, éstas actuaron con violencia contra aquellos vecinos culpados de "inobediencia" y "desacato"81. El castigo de cárcel y confiscación de bienes que les impusieron contribuyó, sin duda, a que el austracismo se extendiese en los años inmediatamente posteriores, sumándose muchos de ellos al levantamiento de la ciudad de Cartagena a favor del archiduque Carlos. Ese fue el caso de su alcalde pedáneo de 1706, José Albaladejo, "[...] uno de los que fomentaron la sublevación de Cartagena", el cual sería relevado por el más filipista Ginés de Vera Llorente

Cartagena", año 1695, ante Luis de Guevara, escribano de Mula. En 8.11.1695 Alonso Gálvez, alcalde ordinario de Fuente Álamo de Cartagena, ordenó a Pedro Martínez, escribano de Fuente Álamo, que protocolizara el poder en sus registros, dando traslados, y en el mismo día Gregorio Reillo lo sustituyó en Matías de Moya.

74 J. D. Muñoz Rodríguez, La Séptima..., pp. 64 y 217.

75 AML, Ac.Cap. 25.9, 13, 20, 30.11.1694, 12.3, 2.4, 4.6.1695, 25.4, 1, 19, 22.5 (Concordia), 18, 19, 26.8, 10.11.1696. Otras declaraciones en AML, Ac.Cap. 11.12.1694 (cartas de Murcia y Cartagena), 8.1.1695 (búsqueda de papeles en el archivo), 22.3.1695 (ayuda al oficial para escribir la probanza del pleito).

76 AMM, Ac.Cap. 1697, Cabildo Ordinario (CO) de 20.8.1697: carta del regidor de Cartagena don Juan Lorenzo Rato.

77 AHPM, Fondo Exento de Hacienda, libro 4.016, n. 451, fs. 390-417, traslado escrituras de 8.7.1696.

78 En un testimonio de la constitución del Ayuntamiento de Fuente Álamo en 1812 (ARChG, sala 321, legajo $4.320, n$. 7) se dice que se estima su población según su demarcación de que antiguamente estuvo en posesión.

79 Sobre la oposición del Ayuntamiento de Murcia al villazgo de Fuente Álamo: AMM, legajos 2.757 (1694) y 3.670 , n. 9 (1697-1700).

80 Real Provisión de 27.1.1701: AMM, caja 27, n. 28. AHPM, Not. 1.724, 6.1 y 31.5.1701, s.f.

81 AMM, leg. 1.021, 1.10.1701 y 3.6.1702. 
en aquel gobierno ${ }^{82}$. Sin embargo, la memoria de esa fugaz autonomía no se perdió en el tiempo, y los vecinos de Fuente Álamo continuaron pidiéndola -por ejemplo, en $1751^{83}$ hasta su obtención definitiva con las reformas liberales del siglo XIX.

Cuadro 1. Configuración de los villazgos vendidos en el Reino de Murcia bajo Carlos II

\begin{tabular}{|c|c|c|c|c|c|}
\hline Nuevos villazgos & Municipios anteriores & $\begin{array}{c}\text { Año } \\
\text { separación }\end{array}$ & Coste & Moneda & $\begin{array}{l}\text { vecinosl } \\
\text { año }\end{array}$ \\
\hline Huércal Overa & Lorca & 1668 & 5600 & ducados & $120(1668)$ \\
\hline Fuensanta & La Roda & 1671 & 7.500 & $\begin{array}{l}\text { mrs.x } \\
\operatorname{vec}^{\circ} .\end{array}$ & $45(1671)$ \\
\hline Nerpio & Yeste & 1688 & 7.500 & $\begin{array}{l}\text { mrs.x } \\
\text { vec }^{\circ} .\end{array}$ & $150(1688)$ \\
\hline Bullas & Cehegín & $1689 / 1692$ & 7.500 & $\begin{array}{l}\text { mrs.x } \\
\text { vec }^{\circ} .\end{array}$ & 167 (1689) \\
\hline $\begin{array}{l}\text { Santiago de } \\
\text { Espada }\end{array}$ & Segura de la Sierra & 1691 & s.d. & s.d. & $242(1691)$ \\
\hline $\begin{array}{c}\text { Fuente Álamo } \\
\text { Murc }^{\mathrm{a}}\end{array}$ & $\begin{array}{c}\text { Cartagena/Lorca/ } \\
\text { Murcia }\end{array}$ & 1700 & 6.000 & ducados & 199 (1694) \\
\hline
\end{tabular}

Fuente: AGS, DGT, Inventario 24, leg. 464, f. 97 (1668): cédula confirmando la exención de Huércal-Overa; CC, 1.983-7: Madrid, 6.7.1671: memorial de los vecinos de Fuensanta al rey; RGS, VI (1688): Madrid, 28VI-1688: merced a la población de Nerpio de eximirla; CC, 2.068: Bullas, 24.6.1690: copia del villazgo de Bullas; y AMM, caja 27, n. 28: Real Provisión de 27.1.1701.

\section{Conclusiones}

Acercarnos a la historia de los villazgos no supone necesariamente encerrarnos en un mundo historiográfico local. Por el contrario, como hemos pretendido sostener a lo largo de estas páginas, los villazgos murcianos del reinado de Carlos II permiten analizar las dinámicas políticas que se daban en la sociedad castellana desde la perspectiva de este mundo en pequeño. No implica asumir por completo el relato emancipador de las nuevas autoridades municipales, ni los discursos contrarios producidos por las ciudades o villas cabeceras legítimamente quejosas por las pérdidas de rentas, sino mostrar el funcionamiento

82 J. D. Muñoz Rodríguez, La Séptima..., p. 275. Extrañamente volvería a ocupar el gobierno del lugar en 1709, protagonizando abusos en la cobranza de impuestos contra vecinos, que determinaría su cese definitivo: AMM, AC 1709, CO 28.5 y 15.7.1709; y AHPM, Not. 2.796: Murcia, 1.6.1709: poder de Francisco Jiménez y Onofre García, vecinos en el lugar de El Estrecho, al procurador Antonio Fernández de Rueda.

83 V. Montojo Montojo, "Rasgos de la estructura familiar en Fuente Álamo (Murcia) a mediados del XVIII", en F. Chacón Jiménez y LI. Ferrer (eds.), Familia, casa y trabajo. Historia de la Familia: Una nueva perspectiva sobre la sociedad europea, Murcia, Universidad de Murcia, 1997, pp. 658-663. 
de las relaciones entre la Corona y los grupos de poder local, sus expectativas, medios y resultados. Relaciones que, por otro lado, estaban enmarcadas en un ámbito de negociación en el que ambas partes perseguían un beneficio particular, y en las que los intereses más inmediatos a los vecinos no constituían un fin primordial.

El déficit crónico de la hacienda de Carlos II pudo ser paliado con la venta de toda clase de bienes y nombramiento reales, además de la creciente colaboración de los recursos locales en la defensa de las fronteras. En ambos casos, la Corona salió ganando pues obtuvo una más estrecha integración de la periferia en las necesidades de la Monarquía, consiguió que se percibiese más presente su autoridad y, no menos importante, contribuyó a dar estabilidad al sistema de dominación encabezado por el soberano. Todos los actores políticos estaban inmersos en el objetivo común de la conservación de la Monarquía, puesto que la resistencia frente a tantos problemas que se presentaban al viejo conglomerado hispánico, además de ser un fin que continuamente se proclamaba, ofrecía a numerosos individuos oportunidades de hacer realidad procesos de movilidad social.

La obtención del villazgo en estas seis localidades murcianas es un buen ejemplo de todo esto que apuntamos. La Corona extraía un beneficio económico directo por la sanción de estos procesos; legitimaba las pretensiones de unas nuevas élites que habían acumulado suficiente patrimonio para pensar en otros estadios más elevados de reconocimiento social; $\mathrm{y}$, a cambio de controlar los recursos locales, se mostrarían dispuestas a colaborar con un soberano que había sido el padre de su república con todo tipo de servicios monetarios o personales que se les demandasen. A falta de fuerzas profesionales, la contribución de los vecinos alcanzaba mayor valor para la defensa de la Monarquía, ya no sólo en los habituales socorros de la costa y Orán, sino en el conflicto bélico que estallaría en los años siguientes. La guerra de Sucesión transformaría este reino en una de las fronteras de guerra más activas, ya que su posición estratégica se revalorizaría al convertirse en el antemural de los reinos andaluces y, sobre todo, pondría a prueba el amor de sus súbditos al monarca borbónico.

En consecuencia, la realidad era mucho más compleja que la presentada por esos discursos libertadores que anunciaban el comienzo de una demanda de villazgo ante Ios tribunales cortesanos; y el camino hasta situar el rollo que simbolizase la autonomía jurisdiccional lleno de dificultades hasta conseguir la aprobación real. Sin negar los abusos a los que se sometían a las aldeas, los intereses que surgían eran múltiples y cruzados; tanto que a muchos castellanos del siglo XVII probablemente les sonasen a ficciones de libertad estas ansias que algunos vecinos mostraban por emanciparse.

\section{BIBLIOGRAFÍA}

Andrés Ucendo, J. I., La fiscalidad en Castilla en el siglo XVII: los servicios de millones, 1601-1700, Bilbao, Universidad del País Vasco, 1999.

Andújar Castillo, F., Necesidad y venalidad: España e Indias, 1704-1711, Madrid, Centro de Estudios Políticos y Constitucionales, 2008.

Aranda Pérez, F. J., "Un reino de repúblicas: comunidades políticas ciudadano-oligárquicas y su representación en la Castilla Moderna", en M. Á. Faya Díaz (coord.), Las ciudades españolas en la Edad Moderna: oligarquías urbanas y gobierno municipal, Oviedo, KRK, 2014, pp. 23-62.

Buendía Porras, L., y Muñoz Rodríguez, J. D., "Nuevos poderes para nuevos espacios. Los diputados de la marina murciana en la vertebración política del territorio (ss. XVIIXVIII)", Murgetana Revista de la Real Academia Alfonso X el Sabio, 107 (2002), pp. 73-91.

Cano Valero, J., "Intentos frustrados de villazgo y exención jurisdiccional del lugar de 
Villamalea en el siglo XVII", Al-basit, 13, (1984), pp. 25-36.

Díez Sánchez, M., La hacienda municipal de Alicante en la segunda mitad del siglo XVII, Alicante, Institución Juan Gil-Albert, 1999.

Domínguez Ortiz, A., Instituciones y sociedad en la España de los Austrias, Madrid, Ariel, 1985.

Espino López, A., Fronteras de las monarquía. Guerra y decadencia en tiempos de Carlos II, Lleida, Milenio, 2019.

Faya Díaz, M. Á., "La venta de señoríos eclesiásticos de Castilla y León en el siglo XVI", Boletín de la Real Academia de la Historia, CC/II, (2003), pp. 101-132.

Felices de la Fuente, M. M., La nueva nobleza titulada de España y América en el siglo XVIII (1701-1746): entre el mérito y la venalidad, Almería, Universidad de Almería, 2012.

Gallego Lázaro, E., "La reorganización de la comunidad de ciudad y tierra de Segovia durante la Edad Moderna. Las ventas de lugares en el siglo XVII", Studia Histórica. Historia Moderna, 38/2, (2016), pp. 387-424.

Garrido García, C. J., y Bravo Palomares, F., "Estudio sociodemográfico de una población de la Sierra de Segura en el siglo XVI: El Hornillo o Puebla de Santiago (Santiago de la Espada)", Boletín del Instituto de Estudios Giennenses, 218, (2018), pp. 89-116.

Gelabert, J. E., "Señoras de sí mismas. La constitución de villas en la España del Antiguo Régimen", en E. Jarque Martínez (coord.), El concejo en la Edad Moderna: poder y gestión de un mundo en pequeño, Zaragoza, PUZ, 2016, pp. 15-42.

Giménez Carrillo, D. M., Los caballeros de las órdenes militares castellanas. Entre Austrias y Borbones, Almería, Universidad de Almería, 2016.

Girón Pascual, R. M., Las Indias de Génova. Mercaderes genoveses en el reino de Granada durante la Edad Moderna (ss. XVI-XVIII), Granada, Universidad de Granada, tesis doctoral, 2013.

González Castaño, J., Caballero Escribano, F., y Muñoz Clares, M., La villa de Bullas (siglos XVII-XIX): Estudio histórico y socioeconómico, Murcia, AAXS, 1991.

Hernández Benítez, M., "Venalidad de oficios municipales en la Castilla del siglo XVIII. Un ensayo de cuantificación", Chronica Nova, 33, (2007), pp. 95-129.

Hespanha, A. M., "Paradigmes de légitimation, aires de gouvernement, traitement administratif et agents de I' administration", en R. Descimon y B. Vincent (coords.), Les figures de l'adminstrateur. Institutions, réseaux, pouvoirs en Espagne, en France et au Portugal, $16^{\mathrm{e}}-19^{\mathrm{e}}$ siècle, Paris, EHESS, 1997, pp. 20-28.

Jiménez Alcázar, J. F., Huércal y Overa: de enclaves nazaríes a villas cristianas (12441571), Huércal-Overa, Ayuntamiento, 1996.

Lemeunier, G., Los señoríos murcianos: s. XVI-XVIII, Murcia, Universidad, 1998.

López Díaz, M., "Espacios y redes de sociabilidad de las oligarquías urbanas en la Galicia moderna: avances y propuestas de estudio", Obradoiro de Historia Moderna, 23, (2014), pp. 139-173.

Marcos Martín, A., De esclavos a señores. Estudios de Historia Moderna, Valladolid, Universidad, 1992.

- "España en almoneda: enajenaciones por precio de alcabalas y tercias en el siglo XVI", en L. A. Ribot García y E. Belenguer Cebriá (coords.): Las Sociedades Ibéricas y el Mar a finales del siglo XVI, tomo IV, Madrid, Sociedad Estatal Lisboa 98, 1998, pp. 25-65.

- "Enajenaciones por precio del patrimonio regio en los siglos XVI y XVII. Balance historiográfico y perspectivas de análisis", en R. López y D. González Lopo (coords.): Balance de la historiografía modernista, 1973-2001. Actas del VI Coloquio de Metodología Histórica Aplicada, Santiago de Compostela, Xunta de Galicia, 2003, pp. 
419-443.

- _La justicia también se vende. Algunas consideraciones sobre las ventas de jurisdicción en la Castilla de los siglos XVI y XVII", en J. L. Castellano y M. L. López-Guadalupe (coords.), Homenaje a don Antonio Domínguez Ortiz, Granada, Universidad de Granada, 2008, vol. 2, pp.469-486.

Molina Puche, S., Poder y familia. Las élites locales del corregimiento Chinchilla-Villena en el siglo del Barroco, Murcia, Universidad, 2007.

Montojo Montojo, V., El Siglo de Oro en Cartagena (1480-1640), Murcia, AAXS, 1993.

- $\quad$ "Señorío y remodelación jurisdiccional y económica en el reino de Murcia: los señoríos de Hoya Morena y Cúllar-Baza (siglo XVII)", en E. Serrano Martín y E. Sarasa Sánchez (coords.), Señorío y Feudalismo en la Península Ibérica (siglos XII-XIX), Zaragoza, Institución Fernando el Católico, 1993, pp. 457-473.

- "Rasgos de la estructura familiar en Fuente Álamo (Murcia) a mediados del XVIII", en F. Chacón Jiménez y LI. Ferrer (eds.), Familia, casa y trabajo. Historia de la Familia: Una nueva perspectiva sobre la sociedad europea, Murcia, Universidad, 1997, pp. 658-663.

- $\quad$ "Las ciudades contra sus aldeas. El estatuto de los lugares en el Reino de Murcia (ss. XV-XVIII)", Murgetana Revista de la Real Academia Alfonso X el Sabio, 106, (2002), pp. 17-35.

- "Los comerciantes de Alicante y Cartagena en la Guerra de Sucesión", Estudis Revista de Historia Moderna, 34, (2008), pp. 219-239.

Montojo Montojo, V. y Maestre de San Juan Pelegrín, F., "Las relaciones comerciales entre el Reino de Granada y el Reino de Murcia en la Edad Moderna", en M. Barrios Aguilera y Á. Galán Sánchez (coords.), La historia del reino de Granada a debate: viejos y nuevos temas, perspectivas de estudio, Madrid, Editorial Actas, 2004, pp. 281-303.

Muñoz Rodríguez, J. D., “¿Divide ut regnes?: Representación e integración del Reino en la Corona de Castilla (1665-1700)" en J. Sobrequé y otros (coords.), Actes del 53 Congrés de la Comissió Internacional per a l'estudi de la Història de les Institucions representatives i parlamentàries, vol. I, Barcelona, Partament de Catalunya, 2005, pp. 257-263.

- "El superintendente austriaco y el intendente borbónico. La evolución de un modelo de gestión de los recursos fiscales en la Monarquía Hispánica", en A. Dubet y J. J. Ruiz Ibáñez (eds.), Las monarquías española y francesa (ss. XVI-XVII): ¿dos modelos políticos?, Madrid, Casa de Velázquez, 2010, pp. 131-144.

- La séptima corona. El Reino de Murcia y la construcción de la lealtad castellana en la Guerra de Sucesión (1680-1725), Murcia, Universidad, 2014.

Nader, H., Liberty in absolutist Spain: the Habsburg sale of towns, 1516-1700, Baltimore, Johns Hopkins University Press, 1990.

Nardi, L. de, "Los donativos voluntarios", América Latina en la Historia Económica, 25/1, (2018), pp. 7-35.

Palomeque Torres, A., "El señorío de Valdepusa y la concesión de un privilegio de villazgo al lugar de Navalmoral de Pusa en 1635", Anuario de Historia del Derecho Español, 18, (1946), pp. 140-228.

Pérez Picazo, M. T., y Lemeunier, G., El proceso de modernización de la región murciana (siglos XVI-XIX), Murcia, Editora Regional de Murcia, 1984.

Ponce Leiva, P. y Andújar Castillo, F. (eds.), Mérito, venalidad y corrupción en España y América, Valencia, Albatros, 2016.

Rodríguez Domenech, M. Á., y Rodríguez Espinosa, E., "El territorio de la Intendencia de La Mancha en el Catastro de Ensenada. Antecedentes, configuración y evolución 
posterior", Revista Catastro, 80, (2014), pp. 89-148.

Rodríguez Llopis, M., "El privilegio de villazgo de Nerpio y su segregación de Yeste", Información Cultural Albacete, 87, (1995), pp. 3-14.

Rodríguez Llopis, M., y Martínez Carrión, J. M., "Las transformaciones demográficas de la población rural. Yeste en los siglos XIV al XX", Áreas. Revista de Ciencias Sociales, 3-4, (1983), pp. 13-54.

Rosa Ferrer, I. de la, "La Superintendencia General de las Rentas Reales del Marquesado de Villena en el siglo XVII. Análisis institucional", en La investigación y las fuentes documentales de los archivos, Guadalajara, ANABAD-Castilla-La Mancha, 1996, pp. 685-709.

Ruiz Ibáñez, J. J., Las dos caras de Jano. Monarquía, ciudad e individuo. Murcia, 15881648, Murcia, Universidad de Murcia, 1995.

- $\quad$ "El final de un sueño imperial: guerra y poder en Castilla tras 1635", Studia historica. Historia Moderna, 41-1, (2019), pp. 259-288.

Ruiz Ibáñez, J. J., y Muñoz Rodríguez, J. D., "Sirviendo a la Corte en la aldea, sirviendo a la aldea en la Corte: Veteranos, agentes y medios de relación en el siglo XVII castellano", en Espacios de poder: cortes, ciudades y villas, Vol. 2, Madrid, Universidad Autónoma de Madrid, 2002, pp. 227-247.

Saavedra, M. C. (ed.), La decadencia de la monarquía hispánica en el siglo XVII. Viejas imágenes y nuevas aportaciones, Madrid, Biblioteca Nueva, 2016.

Sánchez Belén, J. A., "La Junta de Alivios de 1669 y las primeras reformas", Espacio, Tiempo y Forma. Historia Moderna, 4/4, (1989), pp. 639-668.

- La política fiscal en Castilla durante el reinado de Carlos II, Madrid, Siglo XXI, 1996.

Sánchez Belén, J. A., y Alcaraz Hernández, A., "Oligarquía municipal e impuestos: La asonada del campo de Cartagena de 1683", Espacio, Tiempo y Forma, 4/4, (1991), pp. 163-202.

Soria Mesa, E., La venta de señoríos en el reino de Granada bajo los Austrias, Granada, Universidad, 1995.

- $\quad$ "La ruptura del orden jurisdiccional en la Castilla de los Austrias. Una interpretación a la luz del poder local", en J. J. Ruiz Ibáñez (ed.): Cuadernos del Seminario Floridablanca, 4, 2001, pp. 439-458.

- La nobleza en la España moderna: cambio y continuidad, Madrid, Marcial Pons, 2007.

- "Comprando poder: Una aproximación a la venta de oficios en el reino de Granada (ss. XVI y XVII)", en A. Marcos Martín (ed.), Hacer historia desde Simancas. Homenaje a José Luis Rodríguez de Diego, Valladolid, Universidad de Valladolid, 2011, pp. 745762.

Storrs, Ch., The Resilience of the Spanish Monarchy 1665-1700, Oxford, Universidad de Oxford, 2006 [ed. en español, Madrid, 2013].

Thompson, I. A. A., "Patronato real e integración política en las ciudades castellanas bajo los Austrias", en J. I. Fortea Pérez (ed.), Imágenes de la diversidad. El mundo urbano en la Corona de Castilla (ss. XVI-XVIII), Santander, Universidad de Cantabria, 1997, pp. 475-496.

- "Conflictos políticos en las ciudades castellanas en el siglo XVII", en J. I. Fortea y J. E. Gelabert (coords.), Ciudades en conflicto: (siglos XVI-XVIII), Santander, Universidad de Cantabria, 2008, pp. 37-56.

- "Some observations on Crown sales of municipal offices in Castile, 1640-1665", en A. Marcos Martín (ed.), Hacer historia desde Simancas. Homenaje a José Luis Rodríguez de Diego, Valladolid, Universidad de Valladolid, 2011, pp. 763-786.

- _Do ut des: la economía política del 'servicio' en la Castilla Moderna”, en A. Esteban 
Estríngana (ed.), Servir al Rey en la Monarquía de los Austrias. Medios, fines y logros del servicio al soberano en los siglos XVI y XVII, Madrid, Sílex, 2012, pp. 283-296

Truchuelo García, S., "Villas y aldeas en el Antiguo Régimen: conflicto y consenso en el marco local castellano", Mundo Agrario, 14/27, (2013).

- "Irún y Hondarribia: una controvertida historia de discrepancias y consensos", Boletín de Estudios del Bidasoa, 29, (2017), pp. 83-102. 